\title{
Reflexões sobre como fazer trabalho de campo
}

\author{
Carlos Rodrigues Brandẽo*
}

\begin{abstract}
Resumo: Este artigo reflete sobre a vivência da pesquisa de campo e sobre o tipo de conhecimento produzido no encontro etnográfico. Nele são discutidas estratégias pessoais usadas na aproximação inicial com os sujeitos da pesquisa, especialmente em comunidades camponesas, bem como os dilemas éticos enfrentados pelo etnógrafo durante e após a pesquisa de campo.
\end{abstract}

Palavras-chave: metodologia da pesquisa de campo; comunidades camponesas; etnografia.

Para contextualizar um texto itinerante, de um autor andarilho que não precisa ser apresentado: No início da década de 1980, Brandão foi procurado por Niuvenius Paoli para dar um curso de práticas de campo a professores e alunos da UFMG que estavam começando um projeto ligado à Secretaria de Educação do estado de Minas Gerais e pretendia diagnosticar a educação em uma centena de municípios de pequeno e médio porte do estado a fim de propor um modelo de educação no campo. Como ele não teve tempo hábil para isso, ditou numa fita cassete uma série de reflexões sobre suas experiências. Essa fita foi transcrita e o texto mimeografado por Suzana Obler, ajudando a formar muitos pesquisadores desde então. Em 2002, João Batista Almeida Costa da UniMontes, em Montes Claros, conseguiu-me uma cópia quase ilegível desse texto, que tentei adotar para os alunos de graduação na Uece, mas esbarrava na impossibilidade de tirar cópias. Então, Glaudiane Holanda, também da Uece, resolveu ressuscitar o artigo que agora a revista Sociedade e Cultura publica, ${ }^{1}$ fazendo coro à homenagem que a $25^{\mathrm{a}}$ Reunião Brasileira de Antropologia prestou a esse autor que, nascido carioca, adotou-se goiano.

Roberto Lima

* Professor titular da Unicamp.
Cinco de janeiro de 1983: algumas reflexões extraídas da vivência a respeito do trabalho de campo. Esta gravação é feita para o pessoal do MG 2.

$\mathrm{O}$ que eu quero expor aqui nesta fita de maneira nenhuma substitui o que poderia ter sido uma conversa de um dia em Belo Horizonte, o que eu espero que venha acontecer lá ainda ou, quem sabe, até em Estiva, no próprio campo.

Por outro lado, o que eu estou apresentando aqui, de maneira nenhuma, implica uma teoria de trabalho de campo ou mesmo uma metodologia de trabalho de campo. Eu estou deitado numa rede; são quatro horas da tarde de um dia de chuva e, além de ser janeiro, eu estou de férias, ou seja, raros os contextos menos teóricos e metodológicos do que este de hoje, de agora. Então, o que eu me proponho a fazer é refletir

1. Nota do editor: o autor solicitou que organizasse o texto transcrito para que ficasse "com forma de artigo". Neste caso, minha opção foi de apenas suprimir alguns poucos vícios de fala e verificar, no que fosse possível, citações que estavam confusas, tentando manter o ar de conversa franca. Assim, quaisquer incorreções são de minha responsabilidade. Apesar de a pesquisa ter sido "engavetada" por motivos políticos, quem se interessar pelos resultados parciais dela pode consultar os artigos do Cadernos Cedes 11 (Campinas, 1984), organizado por Niuvenius Paoli. 
em voz alta sobre o trabalho de campo, sobre a minha experiência de pesquisa de campo.

Em primeiro lugar, o que eu queria dizer é o seguinte: para mim, o trabalho de campo é uma vivência, ou seja, mais do que um puro ato científico, como talvez pudesse ser um trabalho de laboratório, no caso de um psicólogo experimental, ou a pesquisa de gabinete de um economista. O trabalho de campo, a pesquisa antropológica, para mim, é uma vivência, ou seja, é um estabelecimento de uma relação produtora de conhecimento, que diferentes categorias de pessoas fazem, realizam, por exemplo, antropólogo, educador e pessoas moradoras de uma comunidade rural, lavradores, mulheres de lavradores, pequenos artesãos, professoras das escolas e assim por diante.

Por outro lado, a experiência de trabalho de campo tem uma dimensão muito intensa de subjetividade. Ou seja, ainda que o antropólogo possa se armar de toda uma intenção de objetividade, de obtenção, de produção de dados e informações, os mais objetivos, os mais reais (não sei se com aspas ou sem aspas) possíveis, de qualquer maneira, muito mais do que em outros casos, todo trabalho de produção de conhecimento aí se passa através de uma relação subjetiva. A pessoa que fala, fala para uma outra pessoa. Uma relação entre pessoas que tem uma dimensão social, e uma dimensão afetiva se estabelece. Dados de troca, de sinais e símbolos entre as pessoas se estabelecem inevitavelmente e isso marca não só a realização do trabalho, mas o material produzido por esse trabalho realizado.

Na minha experiência de campo, eu tenho dois tipos de entradas. Uma entrada que poderia chamar para a pesquisa. Muitas vezes é o chegar no campo para conhecer uma comunidade, para, em cima dela, e articulando aquele primeiro conhecimento com dados de estudos de uma proposta de pesquisa, escrever, fazer o primeiro projeto. Algumas pessoas vão chamar de um levantamento prévio, de um survey e assim por diante.

Uma outra entrada se faz quando eu já tenho uma pesquisa definida, definição esta que em nenhuma de minhas experiências foi absoluta, ou seja, sempre o próprio material de campo, sempre a própria experiência do trabalho de campo redefiniu projetos, redefiniu hipóteses de trabalho, redefiniu abordagens metodológicas e assim por diante. Mas, de qualquer maneira, essa segunda entrada se faz quando eu sei o que eu quero pesquisar. Por outro lado, dizer que o trabalho de campo, numa pesquisa antropológica, passa muito pela relação interpessoal e, conseqüentemente, pelo domínio da subjetividade não quer dizer que seja um trabalho espontaneísta, muito pelo contrário. A própria relação interpessoal e o próprio dado da subjetividade são partes de um método de trabalho, por isso que a gente vai falar em observação participante; que vai falar, numa outra dimensão, em pesquisa participante; vai falar em envolvimento pessoal do pesquisador com as pessoas, com o contexto da pesquisa e assim por diante, como dados do próprio trabalho científico. Ou seja, como dados que, em vez de serem tomados como alguma coisa que se põe contra e precisa ser controlada, são tomados como alguma coisa que faz parte da própria prática do trabalho de campo.

Dentro disso, existe um aspecto muito importante, que todo mundo que conhece um pouco de teoria de pesquisa sabe. Um projeto de pesquisa não diz apenas como aquilo vai ser pesquisado. Uma teoria que fundamenta uma hipótese de pesquisa delimita até o que vai ser visto, ou seja, até aquilo que, dentro de um todo de relações sociais, econômicas e políticas, vai ser intencionalizado pelo pesquisador, vai ser objeto de sua própria atenção, da sua própria maneira de observar. Mais do que isso, dentro de um mesmo marco teórico, de uma mesma pauta teórica, dentro, por exemplo, de uma mesma abordagem estruturalista ou de uma mesma abordagem dialética, diferentes ênfases podem ser colocadas, e isso é uma coisa que muitas vezes atrapalha as pessoas quando vão fazer pesquisas.

Eu vou dar aqui um exemplo muito concreto que está atravessando a própria pesquisa que estou realizando agora. Estou fazendo um estudo sobre o trabalho e o saber do trabalho, ou seja, desenvolvo um projeto no qual o que quero saber é como se dão as relações imediatas, diretas, concretas, familiares, interpessoais do trabalho do camponês. Como esse homem, ao longo de 
um ciclo anual agrícola, vive diferentes cotidianos de relação com a natureza e de relação entre pessoas, por exemplo, no contexto propriamente familiar, pais e filhos, mães e filhas, marido e mulher, avô e neto, irmãos que fazem parte de um mesmo grupo doméstico ou que, mesmo morando em casas diferentes, trabalham num mesmo sítio, numa mesma chácara, dentro de um contexto comunitário como numa situação de mutirão. Ou dentro de um contexto, digamos assim, pequeno-empresarial, na situação em que pequenos proprietários em condições de fazer, ou por necessidade, contratam esporadicamente o trabalho remunerado, a força de trabalho remunerada de outras pessoas da própria comunidade, às vezes até de parentes. Dentro disso, quero pesquisar como é que aí, nessa prática econômica que é o trabalho do lavrador camponês, ao longo de um ciclo agrícola, processamse relações através das quais as pessoas aprendem, sobretudo relações através das quais meninos e adolescentes aprendem dentro do próprio trabalho como adultos. Isto é o que eu quero pesquisar.

Claro, dentro dessa minha pesquisa, eu preciso levar em conta a questão das relações socioeconômicas determinantes dos limites daquela prática econômica. É preciso que eu tenha conhecimento de determinantes de concentração da propriedade fundiária, de transformação progressiva do pequeno proprietário camponês num trabalhador rural assalariado de tipo "bóia-fria" e assim por diante. Agora, essas explicações determinantes, que são necessárias para a compreensão daquilo que quero explicar, não são meu objeto direto de pesquisa. É possível, inclusive, que na minha pesquisa eu vá recorrer à documentação a respeito disso na agricultura paulista e mineira, em termos de livros e de levantamentos, deixando que meu trabalho de campo siga daí pra frente.

Bom, é possível que eu tenha perdido o fio da meada porque eu interrompi este depoimento para atender a um longuíssimo telefonema. O que eu estava dizendo era mais ou menos o seguinte: dentro de um mesmo foco de abordagem, essa delimitação do que vai ser pesquisado é o que conduz o próprio olhar, o próprio ouvir, o próprio ver do pesquisador. Um dos problemas que muita gente enfrenta é uma espécie de obsessão pela explicação determinante: é sempre necessário remontar às últimas causas, aos primeiros determinantes, é sempre preciso remontar ao capital. Então, as coisas que muitas vezes são derivadas disso, mas que embora derivadas têm articulações em si, ficam inexplicadas. Por exemplo, nesta minha pesquisa, interessa saber, como base para um momento de introdução que ocuparia duas folhas, o que provocou, do ponto de vista macroestrutural, a situação atual da prática econômica do campesinato da região que estou pesquisando. Agora, o que vou pesquisar lá é como se dá o cotidiano de trabalho entre produtores diretos de produtos agrícolas de gado leiteiro; como diferentes categorias de parentes, de vizinhos, de produtores rurais, agregados, meeiros, assalariados, camponeses se relacionam entre si em função de uma prática econômica que, por sua vez, tem uma dimensão pedagógica, que é aquilo que eu quero pesquisar mais essencialmente.

Este é um dado muito importante, porque é isso o que vou pesquisar. Dentro disso, o domínio da minha pesquisa não é o domínio das relações entre o Incra e o campesinato. Não é o domínio das relações entre os fazendeiros que existem também na região do campesinato. É o domínio das relações internas e diretas dos produtores camponeses, é esse contexto e esse espaço da família, da troca de serviço entre pai e filho, entre irmãos e assim por diante.

Dito isso, vamos discutir um pouco essa questão de como fazer um trabalho de campo. Eu costumo chegar na região onde vou pesquisar e, dependendo do tempo que eu tenha, costumo passar algum tempo de "contaminação" com o local, ou seja, procuro não entrar diretamente numa relação de pesquisa. Não só não invadir o mundo das pessoas com uma atitude imediata de pesquisa, como também não me deixar levar de imediato sem um trabalho de coleta de dados. Eu acho que é muito enriquecedor viver um tempo, que, dependendo do tempo global que você tenha, pode ser um dia, dois, uma semana, até quinze dias, quem sabe até um mês de puro contato pessoal, se possível, até de uma afetiva intimidade com os bares, as 
ruas, as casas, as pessoas, os bichos, os rios (em geral só pesquiso onde tem rio bom para tomar banho) e assim por diante. Conviver, espreitar dentro daquele contexto o que eu chamaria o primeiro nível do sentir, sentir como é que o lugar é, como é que as pessoas são, como é que eu me deixo envolver. Isso é muito bom, porque faz com que a gente entre pela porta da frente e entre devagar. E, por outro lado, é bom também porque essa lenta entrada, eu diria essa mineira entrada, não tem aquela característica de um trabalho invasor em que as pessoas se sentem de repente visitadas por um sujeito que mal chegou ao lugar, saltou do carro e começou a aplicar um questionário. Inclusive às vezes por experiências antecedentes de trabalho: no Incra eu tive de fazer pesquisas assim, saltar, pesquisar, porque eu tinha um dia para trabalhar num bairro rural. Isto é muito ruim. Toca-se apenas o verniz e toca-se num verniz em que as pessoas se defendem até quando podem da invasão de que se sentem vítimas.

A partir dessa primeira experiência, desse primeiro contato, eu me coloco do ponto de vista de me perguntar o que é que explica aquilo que envolve mais diretamente o que eu quero pesquisar. Ainda no caso desta pesquisa minha, o objeto central da pesquisa é o estudo da reprodução do saber no contexto do trabalho. Então, o que é aquilo que eu preciso conhecer porque é o espaço de relações que envolve aquilo que eu quero pesquisar? É o próprio cotidiano do trabalho. Então, neste momento, a minha pesquisa é sobre esse cotidiano do trabalho. Passado esse período de um entrosamento com a comunidade e de um sentir da vida, do fluir da vida da comunidade, eu começo a fazer esse trabalho de compreensão das relações sociais diretas familiares e extrafamiliares da prática do trabalho camponês na comunidade que estou pesquisando. A minha comunidade, para vocês terem uma idéia, deve ser muito semelhante àquelas que vocês vão pesquisar: é um povoado rural de mais ou menos umas 150 famílias, distrito de um município na Serra do Mar, em São Paulo. Isso é o que eu chamo a minha comunidade. E envolve concretamente não só o que nós poderíamos chamar o concentrado urbano, como também toda a área rural compreendida como sendo dessa comunidade pesquisada. Incluo essa própria compreensão ideológica, ou seja, estou admitindo aí os lugares, as pessoas e as famílias que se identificam como sendo desse lugar, como sendo parte dessa comunidade.

Dentro disso, o meu primeiro trabalho se concentra mais numa observação participante. Participante num duplo sentido. Em primeiro lugar, porque se faz estando pessoalmente no lugar e observando e compreendendo aquilo que está acontecendo, por participar da vida cotidiana das pessoas. Eu quero me meter nos bares, dentro da casa, nas manhãs da vida das pessoas, nos lugares de igreja e principalmente nos lugares de trabalho. Quero estar ali vendo o que está acontecendo. E participar em um seguinte sentido também: de que eu me envolvo pessoalmente com o próprio trabalho quando posso. Há momentos em que eu participo de um mutirão, trabalho num mutirão com as pessoas. Não para sentir, não para que as pessoas me sintam como alguém deles, mas que para esse participar faça com que eu me identifique mais de perto como uma pessoa não deles, mas mais próxima deles, daqueles lavradores que eu pesquiso. Esse é o momento em que eu vejo as coisas acontecendo e anoto. Eu tenho uma caderneta de campo e, atento a esses acontecimentos, eu anoto. Por exemplo, uma família em casa, tomando seu café e se arrumando pra sair. Eu anoto as coisas que estão acontecendo, o que eu chamo as sequiências "actanciais", a mulher acordando primeiro e chamando as pessoas da casa, servindo café, as pessoas agarrando as ferramentas, tomando café e saindo. E anoto também o que as pessoas falam, principalmente o que as pessoas falam entre si. É um momento em que eu, inclusive, procuro me retirar um pouco de cena, não me tornar muito visível, me fazer um pouco opaco, para muito mais ver e procurar entender do que perguntar.

Depois, no contexto do trabalho, eu procuro ver as pessoas trabalhando. Existem determinadas relações estruturais que são importantes. Eu nunca mais esqueci do livro do Antonio Candido em que ele mostra como é que existe toda uma lógica através da qual as pessoas 
dividem entre equipes de trabalho uma área de pasto a ser limpa. Como é que aquilo é feito de tal maneira que o resultado é o máximo aproveitamento do trabalho de cada um, uma racionalização camponesa do trabalho agrícola. Procuro observar qual é a relação que se estabelece entre as pessoas. Dentro de uma equipe de parentes, existe um que é aquele que dá as ordens? Ou as ordens já são mais ou menos conhecidas e as pessoas vão chegando e trabalhando? Existe trabalho subordinado? Ele ainda é hierarquizado como ele é hierarquizado numa equipe de pedreiros? Pais fazem um trabalho e filhos, outro? Meninos de diferentes idades fazem trabalhos diferentes? Quando é que o menino começa a fazer o trabalho de um adolescente? $\mathrm{E}$ assim por diante.

Observar direto e anotar. Isso tudo que vai sendo anotado no momento tem uma dupla função. Em primeiro lugar, é material que depois vou usar na pesquisa. Isso, muitas vezes, não é uma coisa tão importante numa pesquisa de prática econômica, mas, numa pesquisa de processo pedagógico, pode ser muito importante: a observação das relações entre professor e aluno, a observação das relações entre diretora da escola, professores, alunos e pais de alunos numa reunião é de uma grande importância. Aquela é uma situação teatral, é alguma coisa que a gente entende muito bem lendo Erwin Goffman ou Victor Turner, cada um a seu modo. As pessoas agem, hierarquizam relações, a ação de uma pessoa determina a ação de outra, o resultado é uma espécie de drama da vida cotidiana. Isso se vê na escola todos os dias de uma maneira mais visível do que numa pequena equipe de trabalho camponês; se vê muito mais ainda num trabalho ritual, no trabalho de uma equipe de foliões de Santos Reis (eu estou voltando de um trabalho com uma dessas equipes em Goiás). Ou, então, dentro de uma festa de amplitude maior, onde tudo que se faz são comportamentos sociais e simbólicos entre categorias de pessoas que a própria situação da festa redefine: foliões, promesseiros, devotos, alferes, embaixadores, dançantes de congo, de moçambique, reis, rainhas, assim por diante; $o$ que as pessoas cantam, dançam; o que as pessoas cerimonialmente trocam entre elas em termos de bens materiais, bens simbólicos, ditos espirituais e assim por diante. Isso tudo não sai apenas da entrevista, uma coisa é o que as pessoas dizem a respeito disso, outra coisa é aquilo que o antropólogo vê, aquilo que o pesquisador vê acontecendo.

Vejam vocês, num primeiro momento, eu procuro ver o que está acontecendo simplesmente, eu procuro anotar descritivamente. Às vezes, essa descrição horroriza o sociólogo, porque ela parece uma coisa tão banal e tão medíocre, tão improcedente para uma pesquisa que pretende dizer grandes coisas, que parece uma banalidade mesmo. Mas leiam com cuidado, por exemplo, O capital, de Karl Marx, para ver como é que grande parte do que está escrito ali são pequenas observações a respeito de como um operário trabalha em uma máquina, de como uma mulher operária se relaciona com um tear, de como uma equipe de operários se relacionam, de como um capataz estabelece relações com os operários, e assim por diante. Marx jamais seria um grande filósofo e sociólogo se não tivesse sido grande observador das pequenas relações interpessoais no contexto da prática econômica. Então é descrever mesmo, descrever a banalidade do cotidiano.

Num segundo momento, essa descrição pode começar a ser articulada. Isso pode ser feito de duas maneiras. Eu tenho um costume que é o seguinte. Vamos supor que esteja no contexto de um mutirão. Estou ali descrevendo o que está acontecendo, as pessoas fazendo isso e aquilo, momento do trabalho, momento do descanso, de uma brincadeira, de cantoria. A partir de um certo amadurecimento do que estou vendo e descrevendo, começo a entender determinadas organizações e relações. Uma hierarquização do trabalho produtivo é uma certa relação, que embora não seja necessariamente hierarquizada e realizada entre iguais, tem uma lógica própria: as pessoas se distribuem para realizar o trabalho assim ou de outra maneira. Então, eu começo ali mesmo, no contexto da observação, a tentar explicar por que as coisas devem ser assim, qual é a lógica subjacente àquilo, quais são as regras de conduta, quais são os princípios operativos daquela relação de trabalho produtivo, de trabalho pedagógico, de 
trabalho ritual. Isso, eu repito, pode ser feito no momento, no ato.

Por outro lado, tenho o costume também de analisar essas relações, esse ver no campo num momento posterior. Aquilo que eu anotei descritivamente na caderneta de campo, quando eu chego em casa, depois de um banho, no lugar onde está sendo a minha sede da pesquisa de campo, passo para um caderno maior. Mas eu não passo apenas transcrevendo com uma letra melhor aquilo mesmo que escrevi no momento em que estava observando o acontecimento, a estrutura de relações, o ritual, a prática do trabalho. Eu já passo tentando explicações, tentando articular o material. Isso é o que eu chamo articular os dados. Essa explicação ainda não é uma análise teórica daquilo que eu captei na minha pesquisa, é apenas uma organização mais compreensiva dos meus dados.

Num terceiro momento que, inclusive, não precisa ser sucessivo - muitas vezes tudo isso está acontecendo ao mesmo tempo -, entra a questão de pedir às pessoas que reflitam sobre a sua prática, que interpretem aquilo que elas estão fazendo e que se interpretem através daquilo que estão fazendo. Isso que nós temos o costume de chamar de ideologia, ou seja, as categorias sociais, experiências de relações sociais que determinam e configuram práticas, a prática produtiva, a prática política, a prática ritual, a prática familiar, e assim por diante... as pessoas têm um pensar sobre isso. Um pensar que reflete uma prática coletiva e uma condição de vida semelhante entre categorias de pessoas, pais, mães, filhos, mas todos camponeses, todos pertencentes ao mesmo universo comunitário, elas têm uma espécie de consistência coletiva para se apresentar, para poder ser compreendida como a visão de realidade daquela coletividade. Então esse é o momento em que eu peço às pessoas que me falem sobre sua prática. No caso ainda da minha pesquisa, num primeiro momento, as perguntas que eu faço são diretamente coladas na prática, são perguntas quase que a respeito de informação: por que se faz assim e não de outra maneira, por que o menino trabalha assim, ajudando o pai.

Como eu dizia, esse primeiro momento é aquele em que eu estou junto com o pessoal.
Imaginemos, agora, a situação de vocês, vocês estão tentando fazer uma pesquisa sobre campo educativo, vamos pensar esse pessoal, esse momento da pesquisa. Então, vocês estão, por exemplo, dentro de diferentes contextos em que conhecimentos são passados entre as pessoas, de que a escola é um, talvez o mais importante no nosso caso, mas um deles. Tem a própria família, outros são as diferentes unidades de vizinhança, outros são instituições da própria comunidade como uma pequena igreja pentecostal, um terreiro de umbanda que foram criados por pessoas do lugar ou, então, uma equipe de trabalho ritual de Folia de Reis ou de congos, outros são agências de mediação, a própria escola, o posto de saúde que oferece cursos, igrejas católicas ou evangélicas ou centros espíritas trazidos por pessoas de fora e que se instalam no lugar e que têm uma prática docente, o trabalho da Emater e de outras entidades.

Então, num primeiro momento, vocês estão observando, estão ali anotando, por exemplo, uma situação escolar ou de aula ou, então, de reunião de pais e mestres ou reunião de preparação de programa de um próximo período escolar, e assim por diante. Vejam vocês, no momento em que se dá essa observação, em que vocês estão anotando o que as pessoas estão fazendo, que posições estão ocupando, estão articulando esse material, algumas perguntas se apresentam, não em termos de pedir às pessoas que interpretem o que estão fazendo ou por que estão fazendo, por que se relacionam assim, mas em termos de pedir a elas que expliquem o que estão fazendo. Claro, está exposta uma pergunta de fito explicativo. Muitas vezes a gente pergunta uma coisa e a pessoa responde outra, isso é algo que se anota também. Essa é a pesquisa que se faz num primeiro momento.

Num segundo momento, aí sim, é possível que interesse a vocês a interpretação que as pessoas têm, se vocês quiserem, o juízo que as pessoas têm a respeito não só da sua prática, mas a respeito das fronteiras entre essas práticas e outras práticas. Por exemplo, uma coisa é perguntar aos pais como eles estão ensinando aos filhos a partir de que idade, quem ensina e quem faz o quê, e outra coisa é perguntar aos pais as diferenças que eles reconhecem entre o 
ensino que eles têm em casa, o ensino de catequese na igreja, na paróquia, e o ensino que eles recebem na escola, e pedir que eles avaliem, que eles categorizem com a lógica da própria comunidade esses diferentes espaços de saber comunitário, até chegar o momento, talvez este seja um ponto terminal na pesquisa, em que, juntando observações com entrevistas, se tem um dado a respeito de como se estrutura um campo de relações de saber. Como é que as pessoas categorizam ideologicamente esse campo? Um domínio familiar? Um domínio comunitário? Um domínio vicinal? Um domínio institucional? Um domínio religioso? Um domínio profano? Um domínio erudito? Um domínio popular? Como é que do ponto de vista da lógica explicativa do pesquisador (da nossa?), como é que nós estruturamos esse campo de saber? E como é que ele é do ponto de vista da ideologia da comunidade ou da ideologia de diferentes categorias de pessoas na comunidade?

Eu vou dar só um exemplo. É possível que um membro da Congregação Cristã no Brasil das Testemunhas de Jeová veja como centro articulador do saber da vida a igreja, e tudo mais é secundário. É possível até que ele considere que espaços que nós consideramos como pedagógicos sejam desagregadores, destruidores. Já, por exemplo, uma pessoa daquela mesma comunidade, camponesa católica tradicional, talvez faça uma redistribuição completamente diferente, em que a igreja vá ocupar uma posição muito menos importante, quase irrelevante. Isso é o que a gente chama muitas vezes uma exegese, ou seja, pedir que as pessoas que nós observamos fazendo alguma coisa, se relacionando, primeiro expliquem aquilo que estão fazendo e, segundo, interpretem aquilo que fazem, as relações que vivem, assim por diante. Esse é o momento em que muitas vezes as pessoas vão dizer não de uma forma direta, mas de uma forma indireta, por que determinadas atitudes delas, como pessoas individuais, e da comunidade, como uma coletividade articulada, são tomadas diante da escola. É possível que a partir da observação e da explicação se tenha um pouco do fio da resposta a essa pergunta: por que os mesmos pais que têm um interesse muito grande em que os filhos participem da escola não têm um interesse eles próprios de participar de um trabalho de envolvimento entre escola e comunidade? Que lugar simbólico, que lugar social é dado à escola pela diretora, pelo professor, pelos pais, pelas pessoas da comunidade que não têm filhos na escola? Isso é algo que se capta observando. Observando as relações que essas pessoas estabelecem entre si dentro do contexto da escola e fora do contexto da escola. Por exemplo, a maneira como nós observamos as pessoas da comunidade tratando as professoras do lugar diz muito a respeito disso. Isso é alguma coisa que se sabe também perguntando às pessoas a respeito.

Uma outra forma de fazer isso (tem um pouco a ver também com a maneira que eu estou tendendo a realizar esta minha pesquisa) é captar a ideologia das pessoas, não através de uma explicação direta (por que isso é assim, por que você faz assim, como é que você vê isso ou como é que você avalia isso, por que você faz dessa maneira e evita fazer dessa outra), mas captar isso pedindo que as pessoas reconstruam uma história que toca isso. Pedir que as pessoas falem sobre como eram, até onde a memória alcança, as relações da prática econômica do campesinato, como elas foram se modificando e como elas são agora. Isso, inclusive, eu aprendi, porque, na verdade, quando se pergunta, muitas vezes, tanto no contexto de trabalho ritual quanto no contexto de trabalho produtivo, por que as coisas são assim agora e como elas se relacionam, é muito comum que as pessoas respondam fazendo a história que explica esse momento atual. Tudo é assim uma história mítica, muitas vezes, que vai ser muitas vezes uma história fantástica no caso da explicação de um ritual como uma dança de Moçambique ou congos. As pessoas vão ligar isso à própria divindade, a um santo, e assim em diante. Às vezes vão até trazer esse santo para aquele lugar para que ele explique como é que isso é, ou então essas explicações vão ser uma sociologia popular, uma maneira como o campesinato interpreta relações sociais em diferentes tempos.

Eu gosto muito de trabalhar nesse momento, fazendo com que minha entrevista tenha dois fios. Um fio é esse que eu chamo a entrevista da descrição colada na prática. É um exemplo 
mineiro, quando, em julho do ano passado, eu pesquisava por alguns dias garimpeiros da região de Diamantina. Eu consegui que um velho fosse garimpar comigo, então fomos só nós dois para a beira do rio. Eu conversava com ele pelo caminho. Quando chegamos lá, eu liguei o gravador e durante algum tempo fiquei em silêncio e ouvindo esse homem garimpar, ouvindo os barulhos do garimpo. Deixei no primeiro momento que ele mesmo falasse. Então, ora ele falava o que fazia: "Olha, está vendo, eu agora estou fazendo isso. Eu estou peneirando com a peneira mais grossa, ela se chama primeira mesmo, para ver se tem algum diamante grande. Eu faço assim, depois eu mexo assim, depois eu mexo assim, porque o diamante ele fica aqui, está vendo, no meio dessas pedras escuras". Então ele ia dando para mim, inclusive, vocabulário. E, a partir dessa fala espontânea, eu ia fazendo perguntas coladas no que ele dizia, sempre coladas. Em nenhum momento eu pedi uma interpretação mais ampla do que isso. Quando, por exemplo, ele dizia as coisas e os nomes, eu pedia que ele repetisse, às vezes, para gravar o nome, eu dizia a ele: "Não escutei bem, como é que é?". Então ele repetia. Quando ele não dizia o nome, eu perguntava: "Vem cá, como é que chama essa pedrinha escura aqui que o senhor disse que o diamante fica perto dela?". Mais adiante eu pedia a ele que, a partir do que estava fazendo, fosse me explicando por que ele fazia. Esse porquê aos poucos ia se colando na vida dele. Por exemplo, por que ele era garimpeiro e não ia para Diamantina trabalhar lá? Ainda era vantagem? Por que era vantagem? Eu começava a pedir que esse homem me interpretasse a prática econômica dele: como eu fiquei apenas alguns dias, eu fiz isso nessa vez. Se eu fosse ficar meses, talvez deixasse isso mais para frente, a não ser que ele, naquele falar mineiro espontâneo, já me fosse expondo essas coisas. A história da vida desse homem saiu espontaneamente. Ele começou a me contar como é que tinha mais diamante no passado. Como é que tinha muito mais no tempo dos escravos. Ele gostava muito de falar desse tempo, ele era negro. Então, eu pedi que ele me contasse desse tempo. Eu dizia: "Seu João, já andei lendo, até, sobre essas coisas de diamante aqui no tempo antigo, dos escravos. Mas tem muita coisa pelo jeito que o senhor está me ensinando e não tinha nesse livro. Me conta um pouco mais, como é que era? Como é que era o regime desses homens (ele usava muito essa palavra - regime)?". Eu colo muito nas próprias categorias das pessoas.

É interessante que todos esses homens, e os mineiros mais ainda, do povo, eles têm categorias de interpretação da realidade como nós temos. É muito comum esses homens usarem palavras como regime, sistema, tempo, pensamento, idéia: no meu pensamento, na minha idéia. Isso são categorias deles. As nossas não são nada mais, nada menos do que uma eruditização dessas categorias. Então, no momento da entrevista, eu colo nas categorias deles. $\mathrm{Se}$, de repente, ele divide os tempos da vida da comunidade num tempo antigo dos escravos, num tempo de alforria, num tempo dos pais e nos dias de hoje, eu uso essas categorias. Então, pergunto: "Então, fala um pouco mais do tempo dos antigos, dos escravos. Como é que era?". Bom, eu ligo esse falar à própria biografia, ou seja, o próprio homem que está me fazendo a história, quando chega num momento em que ele aparece ou aparecem os pais, ele começa a fazer biografia. Então, eu colo como se fosse um fio só. Há um momento em que, ao mesmo tempo, ele está fazendo para mim a história da comunidade, contando das relações sociais, como é que era muito no passado, como é que era no tempo do Juscelino, como é que ficou depois que chegaram as grandes mineradoras, como é que é agora. Está me contando relações sociais do momento presente, por exemplo, como é o trabalho do garimpeiro autônomo, como é o trabalho do garimpeiro meia-praça, aquele que trabalha para um sujeito que lhe paga comida e lhe dá o material, comoé o trabalho do garimpeiro de turma e como é o trabalho do garimpeiro de empresa. Isso tudo vem no fio da história. $\mathrm{E}$ vem no fio da biografia, porque, de repente, ele começa a contar experiências que teve vivendo, duas ou três dessas situações de trabalho.

É claro que a própria entrevista que é feita com a pessoa varia muito, porque as pessoas não são iguais. Quando a gente vai aplicar o questionário careta, daquele em que tudo vem 
pronto, em que as pessoas têm de responder aquilo, a gente uniformiza diferenças. O sujeito pode ser tímido, desinibido, gago, bem falante, que ele tem de responder daquele jeito. Quando se estabelece uma entrevista, mesmo que a gente tenha o roteiro, eu muitas vezes tenho um roteiro, ainda que não me sinta obrigado a cumpri-lo. É muito importante que se respeite a própria maneira como a pessoa se coloca numa entrevista. Existem sujeitos, mineiros são muito assim, que não vão se abrindo logo de saída. É impressionante a diferença entre entrevistar um lavrador mineiro e um lavrador da Paraíba, nesse sentido a diferença cultural é muito significativa. O lavrador da Paraíba agarra o gravador e não pára mais, você pode ir embora e voltar uma hora depois. O mineiro muitas vezes tem de ser perguntado aos poucos, com idas e vindas, para que, aos poucos, ele sinta que pode entrar na entrevista e dizer. E muitas vezes isso nem vai acontecer. É o tipo de informante de quem vai coletar alguns dados e pronto. Ele não entrou na intimidade da pesquisa, ele não vai se abrir, é um direito dele, eu não tenho por que obrigá-lo a fazer o que ele não quer.

A experiência de puxar uma entrevista pelo fio de vida passa muito por aí. Existem pessoas para quem o melhor caminho, em que elas se sentem respeitadas e valorizadas, é quando se perguntam coisas que têm a ver com a comunidade, a partir da experiência delas, a experiência de migrante, de trabalhador, de lavrador, de gente do povo, de artista popular. Para outras pessoas, esse perguntar pela vida ameaça. Então, eles respondem, quando respondem, objetivamente, quando se pergunta como é que se faz aquilo. Muitas vezes é interessante num caso começar a pesquisa por um fio de vida, por uma história de vida e passar pra uma interpretação mais analítica, mais crítica. Chegar até perguntas do tipo: "O senhor não acha que esse regime de trabalho é injusto para o trabalhador?". Isso é uma pergunta lá do fim, às vezes de uma outra entrevista, que já implica, inclusive, uma categoria de valor. O sujeito vai começar a avaliar como interpretação de política popular as relações sociais que ele próprio vive. Muitas vezes, no caso de um líder sindical, o sujeito começa por aí, ele começa já dando de bandeja uma análise sociopolítica das relações de produção naquele lugar, naquela região. Bom, eu tenho um costume que é o de misturar observações e entrevista.

Uma das coisas que eu acho que mais tem comprometido uma certa qualidade de trabalho de campo é que, hoje em dia, esse dado tão rico do ver e compreender, do participar diretamente de relações sociais, e que mais uma vez eu quero dizer, não só é material de pesquisa como é material para ser pensado, para daí se fazer o roteiro da entrevista, isso tem sido abandonado em favor da pura entrevista. E de uma entrevista que se faz com gravador e que é padronizada, uma espécie de questionário mecânico, eletrônico. Claro, eu não nego que isso produza uma riqueza muito grande em termos de dados. Mas o que eu quero dizer é o seguinte: peguem, por exemplo, livros de sociologia ou de antropologia, que sejam de sociedades primitivas ou então do campesinato, e que o pesquisador articulou dados de fontes secundárias, por exemplo, informações de jornal, coleta de outros livros, de fontes como o IBGE, com observações diretas de vida social em suas várias dimensões com entrevistas. Comparem isto com pesquisas em que o único meio de produção de conhecimento foi entrevista, ou seja, aquelas que são análise do discurso. Cada um tem um valor em si, mas, para a explicação daquilo que eu estou querendo na minha pesquisa, ou daquilo que vocês querem na de vocês, aquele primeiro procedimento é muito mais rico, quer dizer, o procedimento em que vocês jogam com o material exegético, com material ideológico em formação, com a fala, com o discurso do sujeito, mas articulado com aquilo que vocês viram, aquilo que vocês compreenderam, como descrições das relações que vocês, mais adiante, estarão tentando interpretar, com o material da fala, do discurso das pessoas que vocês viram vivendo, se relacionando, trabalhando e assim por diante.

Então, num momento da minha pesquisa, eu faço tudo ao mesmo tempo. Ou seja, eu estou anotando no meu caderno de campo as coisas circunvizinhas daquilo que estou pesquisando e as coisas nuclearmente ligadas àquilo que estou pesquisando. Eu me dirijo aos locais, procuro ver as diferentes situações em que aquilo está acontecendo. Uma pesquisa referente a festas 
e rituais religiosos, em que eu vou nesses lugares, as melhores pesquisas que eu fiz a respeito disso foram aquelas em que eu cheguei ao local antes do acontecimento que eu queria pesquisar, convivi um pouco com as pessoas, assisti a ensaios, vivi o contexto da preparação da festa, e depois vivi a festa nas suas diferentes situações: pessoal acordado, se reunindo, começando a fazer a coisa; o pessoal, de repente, vivendo um momento importante do ritual. E eu vivi o depois, depois que a coisa acabou eu fiquei lá, voltando aos locais com as pessoas, indo à casa delas. A memória está quente, as pessoas estão ainda parece que embriagadas pelo que viveram, querem falar, querem comentar, inclusive, querem dizer em cima do que aconteceu. Eu estou coletando, estou anotando. Eu estou, inclusive, fazendo croquis de situações. Como é que, num determinado momento, ou de trabalho familiar ou então de um ritual, as pessoas estão ali organizadas: eu desenho a posição, o pai, o filho ou, então, esse dançador aqui, e assim por diante. Em cima disso, eu estou perguntando às pessoas. Muitas vezes, nesse momento, ao mesmo tempo em que eu estou vendo e anotando, eu estou perguntando às pessoas.

Aquele meu trabalho, Cavalhadas de Pirenópolis, tem muito disso. Aparentemente, é uma pesquisa que não tem nada com o que a gente quer ver, quer analisar aqui. Mas ele ajuda pelo seguinte, porque eu tentei analisar um campo de relações sociais dentro de uma festa. Então, eu observei as Cavalhadas sendo corridas em Pirenópolis. Num determinado momento, eu me sentei na beira do Rio das Almas (afluente do Tocantins, onde se tomam banhos maravilhosos, inesquecíveis) com o sr. Ataliba, que foi o informante único que deu quase que $60 \%$ das informações faladas. E, com ele ao meu lado, tendo visto, inclusive, tendo desenhado coisas, eu fui pedindo explicações. Então, vejam vocês, se eu estivesse baixado de pára-quedas e dito: "Seu Ataliba me conta como é que são as Cavalhadas, me conta como é que as pessoas fazem, me conta por que é isso", o meu aproveitamento da riqueza do ritual seria um. Como eu convivi com as coisas, vi, me emocionei, desenhei, gravei, fotografei, e como eu perguntei em cima disso, meu aproveitamento foi outro. O que eu dizia:
"Seu Ataliba, no momento em que as pessoas estavam fazendo isso, o que isso queria dizer? Por que elas faziam assim? Por que esse homem dava uma flor para aquele outro? Que aquilo quer dizer?". Então, ele me explicava aquilo com o simbolismo dele, que depois eu iria interpretar estruturalmente.

Uma parte das informações do seu Ataliba eram informações como: "Seu Ataliba, quantas pessoas ficam em cada lado?". Isso não é ideologia. "São doze pessoas." Qualquer pessoa me responde que são doze pessoas de cada lado. "De que cor se vestem tais pessoas, e de que cor se vestem tais pessoas?” Dado, informação. Outras eram respostas de interpretação, de exegese. "Seu Ataliba, por que são doze de cada lado? Por que que os mouros se vestem de vermelho e os cristãos de azul?" Aí, seu Ataliba pode dizer uma coisa, talvez seu João vá dizer outra. E eu vou interpretar em cima dessas diferentes falas. Eu acho que isso pode acontecer muito na pesquisa de vocês.

$\mathrm{Eu}$ costumo, para o meu gasto, dizer o seguinte: que numa pesquisa existe um trabalho de observação sistemática. Chegar num lugar e observar organizadamente, fazendo croquis, aquilo que está acontecendo, um acontecimento ou, então, uma estrutura de relações. Pedir material a respeito. Se eu for numa escola, não só observar as relações entre as diferentes pessoas, funcionários, diretoras, professores, alunos, pais e assim por diante, mas, também, pegar material, o estatuto da escola ou algum regimento que diga por que tem de ser assim e não de outra maneira. Outra coisa é isso que eu chamo a observação participante, que é esse conviver mais livre, mais pessoal, com a situação que implica um envolvimento pessoal e implica um participar de momentos, de uma discussão com as pessoas que conversam no sindicato; ou participar de uma dança; ou participar de um ritual religioso; ou participar de um trabalho. Outra coisa é a entrevista que produz dado.

Nas minhas pesquisas, muitas vezes até, eu classifico os meus entrevistados em três categorias. Esse entrevistado de dado é o sujeito pobre de experiência, ou então o sujeito de experiência, mas fechado, de quem eu não consigo na entrevista mais do que alguns dados, mais do 
que algumas informações a respeito de como a coisa é. Depois o sujeito, o entrevistado, o informante que me dá material crítico, que me dá realmente discurso: é o sujeito que fala, que explica, que me diz uma história de vida, que interpreta fatos. Depois, o que eu chamo de informante especialista, o informante que não só produz dados populares com muita precisão, como também é aquele que entende profundamente da coisa, e ele fala como um especialista. No caso de um trabalho camponês, é difícil você localizar esse homem, porque todos são mais ou menos sabedores do mesmo nível, mas, no caso de um trabalho artesanal, no caso de um trabalho profissional qualificado como o trabalho de pequenos fabricantes de coisas numa comunidade rural (o carapina rural, o ferreiro rural, o benzedor, o rezador, o curandeiro), existem pessoas que são especialistas. Então, eles vão oferecer dados de especialista. Vão fazer interpretações de especialistas. Esse seu Ataliba, no caso de Cavalhadas de Pirenópolis, era um especialista, eu tive a sorte de encontrar numa mesma pessoa não só um sujeito que se abria, ainda que timidamente - era um homem muito tímido, mas que empatizou comigo-, como um especialista: ele tinha plena consciência de que, quando ele me explicava aquilo, ele explicava realmente como a coisa é. E quando é. E, quando eu ia perguntar a outras pessoas do ritual, a informação era muito mais pobre e elas terminavam dizendo: "Por que que você não vai conversar com seu Ataliba?". A mesma coisa quando eu fiz meu trabalho, ainda em Pirenópolis, sobre o reinado de Nossa Senhora do Rosário e o Juizado de São Benedito: eu trabalhei basicamente com um homem chamado seu Jackson, um sujeito, inclusive, muito sem graça do ponto de vista de pessoa humana. Se eu tivesse pensando do ponto de vista de tipos interessantes, ele não me atrairia jamais, mas era um sujeito especialista no assunto, quer dizer, aquele que há anos se responsabilizou por aquele trabalho e que, conseqüentemente, sabia me dizer como a coisa é, ou como ele interpreta que a coisa seja. Então, eu entrevistava várias pessoas, diferentes categorias de pessoas, obtendo de cada uma um tipo de material. Mas do seu Jackson, num caso, e de seu Ataliba, no outro, eu obtive dados de um especialista, em cima dos quais eu fiz a minha interpretação.

Quando estou fazendo o meu trabalho de campo, procuro estabelecer três momentos recorrentes, ou seja, três momentos que se interpenetram. Vejam vocês, são momentos sucessivos, mas que acontecem dentro de uma mesma prática, dentro de uma mesma semana. Eu levo algum material comigo de estudo, não material teórico, porque, em geral, atrapalha. $\mathrm{Eu}$ levo outras pesquisas que têm a ver com minha pesquisa. Então, se eu estou pesquisando trabalho camponês, eu levo pesquisas, por exemplo, do pessoal do Museu Nacional a respeito disso. Eu leio aquilo, leio nos meus momentos de cansaço, quando eu estou em casa descansando de entrevistas, de andanças, e assim por diante. Levo o meu projeto, levo as minhas anotações anteriores à pesquisa e de durante a pesquisa. Leio, releio, tento ver até que ponto eu estou dentro de uma proposta de pesquisa preestabelecida, até que ponto meu material de campo está precisando ser modificado, ou se está precisando modificar meu projeto, e assim por diante. Então, este é o momento de estudo, de reflexão. Por outro lado, eu realizo a pesquisa propriamente, aquilo que eu vim falando até aqui, ou seja, eu entrevisto, eu convivo com as pessoas, eu observo, eu anoto, anoto à mão uma entrevista, ou quando uma entrevista é rica e eu quero todo o discurso, eu gravo, então, eu procuro saber se há condições para isso, digo para a pessoa que eu quero gravar, não gravo escondido, eu mostro para ela a fala dela, eu digo para que eu vou usar aquilo. E, num outro momento ainda, eu processo meu material.

Tem muita gente que faz assim: quando está no campo, só faz a pesquisa de campo, vai guardando as suas anotações, os seus desenhos, vai guardando as suas fitas e deixa esse processamento para um momento posterior, por exemplo, para quando voltar para Campinas ou para Belo Horizonte. Eu tenho um costume diferente. Quer dizer, embora eu vá escrever lá depois, eu trabalho meu material no campo mesmo, minhas fitas gravadas eu ouço lá mesmo. Vou fazer uma confissão para vocês: muitas vezes eu chego em casa, vou fazer um pouco de ginástica, vou tomar um banho, ligo o gravador e escuto uma 
entrevista que eu fiz naquele dia. Não só aquilo me reacende idéias, como também me mostra falhas: momentos em que eu estava cortando a pessoa na fala dela, momentos em que eu enfatizei um ponto importante e deixei coisas importantes de lado, momentos em que eu obriguei o sujeito a ir para uma direção de pesquisa que eu queria, enquanto ele queria explorar outra coisa. Então, escuto. Muitas vezes, escutando uma entrevista anterior, eu escrevo aquilo como um roteiro seguinte, que tem de ser objeto de uma próxima entrevista. Às vezes, com um informante eu faço cinco, seis, sete, oito, dez entrevistas. Para vocês terem uma idéia, eu acabei de deixar em Goiânia com um mestre de folia, chamado Aladares, três cadernos de duzentas páginas de desgravações de fita. Setenta por cento desse material foram entrevistas feitas com um mestre de folia só, mestre Messias, que, inclusive, foi mestre desse Aladares. Então, foi um trabalho de anos, desde 1975 eu gravo esse homem, que já morreu. Então eu gravei, tirei tudo que eu precisava para um relatório de pesquisa que eu estou fazendo agora sobre reprodução do saber no contexto ritualreligioso, e devolvi esses cadernos para o Aladares, na situação até interessante, em que a fala de um mestre de folia, que serviu de material para a minha pesquisa, foi devolvida para um discípulo dele que vai poder agora ler aquilo e perpetuar aquele ensino daquele mestre.

Bom, então, no campo eu faço isso. Depois eu tenho esse costume que eu falei pra vocês e que quero voltar a ele. Nas noites dos dias de pesquisa eu pego um caderno, no meu caso é um cadernão de capa preta, desses cadernos de ata, bem costurado e bem grande para não perder, e eu transcrevo coisas importantes. Às vezes, até, quando uma entrevista gravada foi muito importante, eu transcrevo ali na hora, ou a entrevista inteira ou pedaços dela. Por exemplo, eu ponho os acontecimentos do dia 5 de janeiro em Catuçaba, S. Luís do Paraitinga: "Hoje passei a manhã com seu Vicente. Ele tinha de resolver um problema de limpa de um terreno e chamou alguns companheiros para ajudá-lo. Então não foi propriamente um mutirão, mas foi um quase mutirão, e foi o que eu observei essa manhã". Eu começo a descrever isso. Aquilo que eu copiei ali em cima da perna na hora, eu recopio de uma forma mais articulada, eu desenho com croquis, às vezes eu ponho um desenho, coisas da minha observação e coisas de uma entrevista, ou de uma entrevista ou de um momento em que eu liguei o gravador e deixei as pessoas conversando livremente. Esse é o momento, vejam vocês, que eu tenho não mais o que eu chamaria de dado bruto, que é a minha pesquisa tal como ela está na fita ou na minha caderneta de campo, e nem o relatório, que já é o meu material interpretado, descrito, analisado. Eu tenho o que eu chamo o dado articulado.

$\mathrm{Eu}$, muitas vezes, ali já faço uma espécie de pré-articulação com o material teórico. Por exemplo, eu venho descrevendo esses acontecimentos dessa manhã e digo: olha, isso tem a ver com coisas que a Maria Isaura Pereira de Queiroz descreve num trabalho camponês em tal bairro na periferia de São Paulo e tem a ver também com o que eu li em tal autor a respeito de uma comunidade camponesa na Irlanda. Por outro lado, analisar até que ponto essas relações não são relações de tal modo, porque trocas de serviços agrários ainda não estão passando por uma relação plenamente capitalista, ver isso em tal pessoa e tal pessoa, em Karl Marx, José César Gnaccarini, Niuvenius Paoli e José de Souza Martins. Eu não estou ainda discutindo, eu estou apenas tentando ligar fios, quando eu for escrever meu relatório de pesquisa, aí eu lanço mão de tudo. Aí é o momento em que retrabalho o meu material. Aí eu já estou em casa, eu vou reouvir minhas fitas, vou pagar alguma pessoa para transcrever essas fitas para mim. Eu costumo fazer o seguinte: transcrevo essas fitas, batendo à máquina com uma cópia ou duas. Estabeleço um código, por exemplo, C-01, Catuçaba, o lugar onde estou pesquisando, fita $\mathrm{n}^{\circ} 1$. Então eu guardo o original na íntegra, que é o discurso completo de um lavrador desse povoado, depois, numa cópia, eu recorto momentos da entrevista que têm a ver com diferentes assuntos: quando ele está explicando como era o trabalho camponês no tempo antigo; quando ele está explicando um momento fundamental de transformações, como a introdução do gado leiteiro nessa área, ou a concentração da propriedade fundiária; quando ele está expli- 
cando as relações atuais de trabalho; ou quando ele está explicando dados tecnológicos do trabalho de agricultura do milho ou do feijão. Claro, em cima da minha proposta de pesquisa, eu sei quais são os tópicos que me interessam. Então, eu posso fazer um fichário. Eu recorto os pedaços da entrevista, colo em fichas. Eu vou fichando, por exemplo, descrição das relações de trabalho no passado, descrição das relações atuais entre fazendeiro e camponês, descrição das relações atuais da família camponesa, descrição das relações atuais entre camponeses, observações sobre tecnologia do trabalho agrícola, mitos e histórias populares ligadas ao trabalho, e assim por diante. Então, em pastas eu tenho as entrevistas completas, e dentro desse fichário eu tenho essas mesmas entrevistas recortadas por assuntos, e nos meus cadernos de campo, nas minhas cadernetas, eu tenho as minhas observações. Muitas vezes eu anoto na caderneta de campo: ver fita $\mathrm{C}-03$ de 5 de janeiro de 83 , ou seja, eu entendo que aquilo que eu estou descrevendo ali está naquela fita, ou como uma gravação feita no momento em que as pessoas trabalhando estavam conversando, ou numa entrevista que eu fiz com alguém. Eu tenho as entrevistas completas, as entrevistas fragmentadas e classificadas por assunto dentro de um fichário e o meu material de campo. Além disso, nesses cadernos maiores, eu tenho esses dados já articulados, produto de um material antecedente, que foi processado no campo e que eu posso continuar processando depois.

Quando eu vou fazer o meu relatório, eu aí vou estabelecer o meu roteiro do relatório de pesquisa, que nem sempre é o roteiro do projeto, que muitas vezes até é o projeto muito modificado. Aí, o meu primeiro trabalho, qual é? Estabelecer que tipo de material eu tenho para cada um dos meus momentos de análise. Se vocês quiserem, para a introdução, para o primeiro capítulo, para o segundo, para o terceiro, para o quarto, para o quinto, para o sexto, e para a conclusão. Que entrevistas, que tópicos do meu fichário, que lugares de meu caderno de campo, que lugares desse cadernão com material articulado. Mais adiante (isso é papo para uma outra fita, uma outra conversa aí em Belo Horizonte) eu vou relacionar isso com livros, artigos, monografias, que têm a ver com a minha pesquisa. E livros, artigos, cuja teoria também tem a ver com a minha pesquisa. Então, de repente, eu tenho todo o material classificado e articulado.

Muitas vezes até, no campo, eu já estou fazendo esse trabalho, como eu digo a vocês, ao mesmo tempo em que estou observando lavradores trabalhando, convivendo com eles e entrevistando e ligando o gravador para captar falas espontâneas, eu estou lendo outras pesquisas a respeito. Então, muitas vezes, nesse caderno grande, eu repito, eu já coloco: esses dados tão importantes para determinado momento em que eu pretendo estar explicando certas transformações dentro da família camponesa com relação ao trabalho estão, principalmente, na entrevista que eu fiz com seu Vicente, fita CA03, na entrevista que eu fiz com seu João Vaes, fita PO-08, na entrevista que eu fiz com seu Jonas, fita FE-05, na caderneta de campo $\mathrm{n}^{\mathrm{o}} 3$, das páginas tal a tal, aqui, nesse caderno de organização dos dados, de tal a tal lugar, de tal a tal página, algumas observações importantes eu encontrei no Vapor do diabo, do José Sérgio Leite Lopes, principalmente no quinto capítulo, e encontrei também no A nação dos homens, da Lígia Sigaud, no capítulo $6^{\circ}$, isso tem a ver com alguma coisa que eu andei lendo no Antonio Gramsci, quando ele vai falar do campesinato do sul da Itália em tal livro, em tal capítulo. Isso já é uma articulação de dados. Eu só estou explicando aqui, porque, muitas vezes, eu faço isso lá no local da pesquisa.

Não sei se valeria a pena, dentro dessa conversa, voltar a coisas muito simples para discutir certos procedimentos de pesquisa. Quando eu chego numa comunidade, eu procuro, em primeiro lugar, chegar com algum conhecimento prévio. Então, para dar um exemplo, quando a minha pesquisa é num povoado, eu vou na sede do município e lá eu entro em contato com as instituições estatais, municipais, religiosas, particulares, políticas, que possam me fornecer dados a respeito: a Emater; o serviço de erradicação da malária, que, pelo menos em Goiás, tinha mapas excelentes, localizando casa por casa, de cada povoado; o Incra, que me emprestou em Goiás cadastros de propriedades 
fundiárias; a "Casa do Agricultor"; a Secretaria de Saúde; a Secretaria de Educação; outros setores da prefeitura; a paróquia católica; uma igreja evangélica; o sindicato do trabalhador rural; uma escola de samba, e assim por diante. Mapas, listagens, documentos.

Uma outra coisa que eu gosto de fazer é ler a respeito daquele lugar nos livros que, porventura, tenha. Em Minas Gerais, era muito comum nos municípios se fazer almanaques. No sul de Minas isso é comuníssimo, Almanaque de Pouso Alegre 1936; então, embora seja feito por leigos, não-especialistas, tem muitos dados a respeito da própria história do lugar. Tem muito, inclusive, a ideologia das classes dominantes, de intelectuais eruditos dessas classes do lugar. Às vezes, a gente vai encontrar material do que eu chamo os pequenos sábios do lugar, quer dizer, pessoas da comunidade, um advogado, um juiz, um professor que escrevem sobre o lugar. Ainda ontem mesmo eu estava lendo um livro horrível do ponto de vista de português e do ponto de vista da explanação de uma vida comunitária, mas importantíssimo do ponto de vista de dados, que era um livro escrito por uma mulher moradora em Itapirapuã e resolveu fazer um livro sobre a terra natal. Isso em Minas deve ter aos montes. Na minha pesquisa sobre a cultura do garimpeiro em Diamantina, muita coisa eu vou obter de livros antigos e atuais, inclusive de documentos sobre Diamantina. Eu trabalho com mapas, com dados censitários, com esses livros, livrecos, almanaques, artigos e assim por diante. Fora material de pesquisa que evidentemente tem a ver com isso. Por exemplo, na minha pesquisa na Serra do Mar, embora não esteja pesquisando no município de Cunha, eu tenho o trabalho do Emílio Willems sobre Cunha, Uma vila brasileira: tradição e transição, e tenho o trabalho de Robert Shirley, O fim de uma tradição. Então, eu vou trabalhar em cima desses dados, porque aqui, embora não seja o mesmo município, certas relações antigas e atuais de produção de vida social têm muita compatibilidade, então isso me ajuda, isso me faz a cabeça. Eu chego no lugar já com esses dados. Quando, por exemplo, o município tem jornal, muito comum em São Paulo e no sul de Minas, desde o passado, e quando eu tenho tempo, porque eu não gosto muito de trabalho com arquivo, eu vou aos jornais. Na minha pesquisa de Itapira, dos Deuses do Povo, eu fiquei um mês e meio trabalhando com jornais, porque no caso era muito importante, pois eu estava reconstruindo a história política das religiões do lugar e os jornais, sobretudo nos anos do passado, fim do século XIX e meados deste século $\mathrm{XX}$, produziram muito material a respeito. Quando eu chego lá, na comunidade, eu já chego com esse conhecimento prévio.

Quando eu chego na comunidade, num primeiro momento, como disse a vocês, não vou diretamente às pessoas com quem quero trabalhar. Se eu vou fazer uma pesquisa sobre a vida religiosa do lugar, não vou diretamente aos agentes religiosos, a não ser que seja o que eu chamo uma pesquisa de emergência, quando estou num lugar onde eu só vou aquela vez, quero obter dados para escrever um artigo, tenho apenas aquela semana, então não posso me dar ao luxo de passar aquela semana fazendo um trabalho de aquecimento e de me dar a conhecer, mas, quando eu tenho condições, eu não vou diretamente. Eu procuro ir contactando pessoas a esmo. O dono de um bar, a pessoa que está me acolhendo na sua casa, pessoas que eu encontro na rua, e assim por diante. Apenas um parêntese machista: é verdade que, dentro da cultura em que a gente vive, tudo isso é muito mais fácil para homem do que para mulher. Eu reconheço que uma das áreas onde há uma injustiça social muito grande é nessa área de pesquisa de campo. Por exemplo, eu posso entrar com uma grande tranqüilidade em qualquer bar, beber pinga com as pessoas e daí tirar uma camaradagem que produza dados. Quero ver a Derly fazer isso. Ela vai ter de entrar através de mulheres, vai ter de chegar devagarinho, conversar com donas de casa, conversar com a freirinha do lugar, quer dizer, ela vai ter de entrar pela porta, que não faça com que a comunidade estereotipe sobre ela, então, isso é uma porta de entrada, entrar por aí.

Bom, se eu tenho definido o que eu quero pesquisar, se estou sabendo com que categorias de sujeito eu quero trabalhar, a partir do momento em que esse aquecimento, que eu descrevi no começo da fita, foi feito, eu começo a ir às 
pessoas. Eu, em geral, dou uma explicação do porquê que estou fazendo essa pesquisa, que não precisa ser a explicação verdadeira, inclusive, porque, muitas vezes, as pessoas nem sabem entender. Eu digo que sou um professor de colégio, que estou tentando reconstruir a história daquele lugar, que tenho interesse em conhecer os costumes, e assim por diante. Muitas vezes até, eu perco um tempo em deixar que as pessoas forneçam um dado que não é interessante, para que as pessoas forneçam um dado que é mais fácil para elas. Aquilo que eu já tinha falado também quando eu estava discutindo as categorias de entrevistas. A partir daí, as pessoas às vezes começam a falar: "Bom, aqui tem isso, aqui tem aquilo". Não é o que me interessa, mas é por onde a pessoa liga um fio, entre aquilo que ela acha que eu quero e aquilo que ela sabe falar naquele primeiro momento. Então, eu vou por aí também. A partir daí, eu não só começo a conversar com as pessoas, como eu começo a fazer um inventário de informantes, que é perguntar para elas quais são as pessoas que elas acham que poderiam me ajudar mais nisso que eu quero. Quando a pesquisa é bem definida, como essa pesquisa de reprodução de saber, no momento que as pessoas entendem, elas têm dados objetivos: o senhor vai procurar a professora tal, sobre isso o senhor vai procurar o seu Messias, que é o sujeito que entende muito desse assunto de benzeção, sobre essa questão de trabalho você vai procurar tal pessoa, e assim por diante.

Então eu faço esse inventário e começo a ir nas pessoas, eu uso muito o seguinte: pedir que pessoas me levem a pessoas. Isso ajuda extraordinariamente. Quer dizer, no momento que você fez familiaridade com uma pessoa, que você não é mais um estranho e que você já entrevistou, já ouviu, já cantou, já bebeu pinga com aquela pessoa, coisa que eu posso fazer com liberdade e que a Derly vai ter de fazer com grande moderação, eu peço a ela que me leve a outra pessoa, um compadre, um vizinho, um alguém. Então, o relacionamento com essa outra pessoa já fica muito mais fácil. Não é raro, inclusive, que eu vá a essa segunda pessoa com a primeira e, com a segunda, eu faça uma entrevista a três, a primeira, a segunda e eu. Eu uso muito de fazer entrevista dentro de um contexto coletivo. Se eu estou no meio de uma Folia de Reis, em vez de conversar com o mestre, com o alferes, com o folião sempre numa relação dual, chega num determinado momento, por exemplo, que tem uma gente comendo numa sala de casa, eu entro lá, com meu prato na mão e puxo o assunto em geral. Eu evito muitas vezes, sobretudo nessas situações, essa entrevista profissional, que é uma coisa, às vezes, horrorosa, imaginem vocês: uma pessoa entrar pela casa de vocês, se apresentar, sentar e começar malhar vocês de perguntas. Eu prefiro fazer diferente. Eu prefiro provocar a produção de material, em cima de uma observação. Eu sento e digo: "Oh, pessoal, mas vocês cantaram bonito agora, heim? Faz muito tempo que eu não ouço um cantorio tão bonito". Disse alguma coisa que faz com que as pessoas se sintam empaticamente ligadas a mim e digo alguma coisa que vai produzir das pessoas um comentário. "É. A gente cantou bem. É porque aqui nessa casa a gente canta com muita vontade, porque o dono dela é um folião muito amigo, é o velho que a gente quer muito bem." Eu provoco, eu deflagro e deixo o pessoal seguir aí em frente. Essa pesquisa coletiva às vezes fica um pouco difícil de ser desgravada, porque, só ouvindo as pessoas, a gente não sabe quem está falando o quê. Mas, por outro lado, ela tem uma riqueza muito grande, porque as pessoas estão mais soltas, e porque as pessoas vão se desafiar mutuamente. A mesma coisa que a gente vê quando, na televisão ou no rádio, assiste a um intelectual interpretando as eleições e assiste a uma mesa-redonda, em que sujeitos de tendências diferentes ou de tendências semelhantes, mas com opiniões diferentes, estão interpretando aquela situação.

Então, vejam vocês, para concluir esta fita e a nossa conversa. Por que não tem muito livro de métodos e técnicas de pesquisa em antropologia? Porque, embora haja teoria antropológica, método de pesquisa, ou melhor, métodos de pesquisa, abordagens diferentes, a prática da pesquisa vai muito em cima de uma relação pessoal. Eu nunca aprendi entrevista, eu acho que eu tenho muito de aprender ainda, em cima de manual. Já li, já li entrevistas, já li manuais de 
entrevista, na psicologia tem muitos manuais de entrevista psicológica, manuais até de entrevista terapêutica. $\mathrm{Na}$ antropologia é mais raro. A observação, o ver, o anotar, a entrevista, a pesquisa sistemática, o momento participante vai muito da pessoa. O que eu acho que educa e ajuda a gente é cada um descobrir o seu estilo, ou seja, ainda que a proposta seja coletiva, e ainda que a abordagem teórica seja uma, assumida por todos, a prática concreta da pesquisa é uma coisa que vai pela relação pessoal e aí cada um tem de descobrir o seu estilo.

Claro, algumas coisas devem existir como regras. Existe uma regra muito importante, é curioso como é que algumas coisas não passam pela cabeça de certos pesquisadores, o pesquisador, ele pode ser militante do PT, mineiros podem ser do PMDB, mas de preferência do PT. Bom, no momento da pesquisa, ele é um pesquisador. Não quer dizer que ele seja um sujeito neutro do ponto de vista positivista, mas ele é um sujeito que não emite necessariamente juízos de valor sobre a conduta social ou simbólica dos outros, para não condicionar as respostas dos outros. No momento em que um lavrador está me interpretando a sua visão real, se essa visão for terrivelmente alienada do ponto de vista dessa estranha coisa chamada consciência de classe, eu não tenho nada que ver com isso. Se eu começar fazer ver a ele ali, no momento, que o que ele está me dizendo é uma impropriedade, é um absurdo do ponto de vista do pensar de uma pessoa que é explorada e não se reconhece como tal, ele, ou vai se fechar, ou vai começar a fazer aquilo que eu chamo a resposta de espelho: ele vai responder para mim aquilo que ele quer dizer, porque é aquilo que ele pensa que eu quero ouvir. Mineiro, então, é especialista nisso. Vocês sabem muito bem, vide o nosso governador, o eleito [Tancredo Neves]. Este é um dado importante. Como a pesquisa implica uma relação ameaçadora, ou seja, eu estou intervindo em vidas, eu estou fotografando, gravando, anotando... eu estou captando segredos, opiniões, atitudes e provavelmente não vou devolver nada em troca, a comunidade joga com essa relação, cada pessoa joga com essa relação. Produz informações, se deixa fotografar, se deixa gravar. Às vezes, até gosta muito. Às vezes, até se aborrece quando a gente vai e não leva o gravador. Dá informações. Opina. Mas, sobretudo no começo do trabalho, quando o grau de confiabilidade ainda é pequeno, muitas vezes faz isso através de uma atitude defensiva, que é essa de um espelhar a sua resposta, ou seja, ao invés de dizer a coisa como pensa, ela diz de uma maneira não comprometedora e ao mesmo tempo de uma maneira não ofensiva, ou seja, muitas vezes, para o camponês, dizer uma coisa que ele pensa que é o que a gente não quer ouvir é alguma coisa que nos ofende, e por isso ele só diz o que a gente quer ouvir. Então, é preciso ter um cuidado muito grande para ser sensível a essa possibilidade da resposta cortêsespelho, esse é o momento em que, sem interferir com o juízo de valor, a gente pode fazer questionamentos em cima da entrevista, para que o informante se sinta obrigado a se definir. Um exemplo: ele está dizendo que ele trabalha em terra alheia, recebe na meia, e depois de descrever como é que ele trabalha, o seu regime, o seu "rejume", como dizem alguns, ele vai dizer que é assim mesmo. É o momento em que posso dizer: "Mas seu João, o que que o senhor acha, por exemplo, se cada lavrador como o senhor tivesse a sua própria terra?". "Ah, aí era bem melhor." "E o senhor acha, seu João, que isso podia acontecer?" Ele vai dizer. Se ele disser que não. "Por quê?" Se ele disser que sim. "Por quê?" As perguntas se sucedem. No momento em que a gente sente que o seu João se fecha, é porque ele está sendo ameaçado com essas perguntas. Então, talvez seja a hora de retornar um pouco aquém e dizer: "Bom, seu João, vamos voltar naquela história que o senhor estava me contando, como é que o senhor planta feijão?". Jogo de cintura pessoal, capacidade de sentir através das pessoas, não através da gente. Eu tenho um roteiro, mas o meu principal roteiro é minha sensibilidade, a minha vivência. Eu tenho a impressão que o melhor mestre de cada um de nós é cada um de nós. Então eu acho que se, de um lado, vale a pena fazer ouvir essa fita, discutir, ler algum manual de pesquisa, acho que muito mais importante é trabalhar no campo o tempo todo revendo o material de campo. Então eu volto àquilo, reouvindo fitas, voltando às anotações. Perguntando-se se coisas que devem 
estar sendo conhecidas estão sendo conhecidas. O que é que está faltando. Quais são os pontos de resistência. Quais são as coisas a respeito das quais está sendo difícil perguntar. Está sendo difícil responder, por quê. Ter consciência de que numa pesquisa, muitas vezes, a coisa mais importante são as respostas que não foram perguntadas, as coisas que fluem e saem livremente. Ser capaz de fazer com que o próprio trabalho de pesquisa, constantemente reouvido, reavaliado, ali na própria situação de campo ou individualmente ou coletivamente, seja o fio do aprendizado da própria prática de pesquisa. Isso é uma coisa que eu acho que ajuda muito e é por onde eu tenho procurado aprender aí.

Bom, a fita está terminando. Vamos ficar por aqui. Nós temos mais ou menos uma hora de gravação, quase sem interrupção. Eu espero que isso seja útil para vocês. Eu acho que em outros momentos nós poderíamos trabalhar, aí sim, numa relação face a face, discutindo, quem sabe, a partir do material de campo de vocês num determinado momento. Como poderia ser o retorno e como, inclusive, esse retorno poderia ser produtivo.

Gente, um feliz 83 e bom trabalho de campo. Até a próxima.

\begin{abstract}
This essay deals with the experience in field work and the kind of knowledge produced by the ethnographyc encounter. Here are discussed personal estrategies that can be used in inicial dialogic approach, especially in peasants communities, and the ethic dilemmas faced by the ethnographer in the field work and at home.
\end{abstract}

Key words: field work methodology; peasants communities; ethnography. 